\title{
Supply-chain corporate venturing through acquisition: Key management team retention
}

\author{
Timothy Kiessling a, Michael Harvey ${ }^{\mathrm{b}, \mathrm{c}, *}$, Miriam Moeller ${ }^{\mathrm{d}}$ \\ ${ }^{a}$ Bilkent University, Turkey \\ b Department of Management, School of Business, Technology, and Sustainable Development, Bond University, Australia \\ ${ }^{\mathrm{c}}$ Department of Management, School of Business Administration, University of Mississippi, Oxford, MS 38677, United States \\ ${ }^{\mathrm{d}}$ University of Queensland, Australia
}

\section{A R T I C L E I N F O}

\section{Keywords:}

Resource base view

Acquisitions

Psychological contract

Corporate venturing

Inter-organizational relationships

Supply-chain management

\begin{abstract}
A B S T R A C T
Acquisitions are often used as a way to engage in corporate venturing. The value of these ventures tends to reside in the knowledge and capabilities of the key management team members who have and maintain key inter-organizational relationships. Because their knowledge and/or relationships may be tacit and therefore difficult to transfer, retaining the key managers in the acquired organization is often a critical issue for the human resource management of the acquiring organization. They are also frequently thought to be critical elements in the future performance in global supply chains and therefore, should be a key concern of human resource management after the acquisition has been culminated. Using a unique dataset of corporate acquisitions in supply-chains, we examine how the development of the psychological contract elements affects retention of critical key global managers. We find that higher retention of the key management team members leads to higher performance after acquisition. We also find that the development of the psychological contract has a positive impact on the retention of key managers with global supply-chain relations.
\end{abstract}

(c) 2010 Elsevier Inc. All rights reserved.

\section{Introduction}

In 2007, merger and acquisition (M\&A) deals worth $\$ 4.367$ trillion were announced, up from $\$ 3.4$ trillion in 2006 to $\$ 2.9$ trillion in 2005 (Moshieri \& Campa, 2009; Wall Street Journal, 2006). The total value of global M\&A fell by $\$ 1.1$ trillion due to the global economic crisis for 2008, with volume dropping from 15,256 deals throughout 2007 to 12,018 deals in 2008 (Hodges, 2009). Within a broader corporate context, the motivation for acquisitions can vary. For example, in the 1980 s, much of the M\&A activity was focused on hostile takeovers as a means to restructure poorly performing conglomerates (Montgomery, 1994). But, in November 2009 M\&A buyout activity rebounded to $\$ 323$ billon the highest month since July 2008 (Kalwarski, 2010).

From an agency perspective, this acquisition activity in the 1990s was motivated through the market for corporate control with an ultimate goal of restructuring these firms for efficiency and discipline over management through the reduction of free cash flows (Jensen, 1986). More recently as global competition is now the norm,

\footnotetext{
* Corresponding author at: Department of Management, University of Mississippi, Oxford, MS 38677, United States. Tel.: +1 662915 5830; fax: +1 6629155821 .

E-mail address: mharvey@bus.olemiss.edu (M. Harvey).
}

acquisition activity has been seen as a means by which an organization can extend its competencies incrementally (Chang, 1996). This view of M\&A activity is consistent with the resource based perspective (Barney, 1986, 1991) wherein an organization seeks to increase their capabilities relative to skills as well as increase their scope of operations through strategic acquisitions. Because a firm typically possesses unused capacity, diversification to extend the use of the firm's resources and frequently capabilities generates net benefits (Penrose, 1959; Wright, Dunford, \& Snell, 2001). Additionally, acquisitions from this perspective provide the opportunity to develop new capabilities both within the acquired unit and within the corporate parent particularly when the acquisition is in a global supply chain (Markides \& Williamson, 1994).

It is apparent that the merger and acquisition strategy continues to be popular for competing in the fast paced global marketplace of the 21 st century. This is typically true in global acquisitions that are centered on global supply-chains. The Council of Supply Chain Management Professionals state that global supply chain encompasses the planning and management of all activities involved in sourcing, procurement, conversion and logistics management. The operational expectations of global supply chain management include the crucial components of coordination and collaboration with channel partners, which can be suppliers, intermediaries and third-party service providers, as well as consumers (Hult, Tomas, Hurley, \& Knight, 2004). 
The bottom line is that global supply chain management integrates supply and demand management within and across companies (Flint, 2004; Handfield \& Nichols, 2004; Vickery, Calatone, \& Droge, 2006). Recently, the acquisition of global supply chains has been seen as a way for firms to engage in obtaining and leveraging new resources through corporate venturing (Thomson \& McNamara, 2001). In particular, acquisitions may form a critical component of external corporate venturing (Miles \& Covin, 2002). Within this stream of research, acquisitions serve many purposes including: as a means to overcome learning distance between supply-chain members (Busenitz, Hoskisson, Arthurs, \& Hansen, 2006), supply-chain members to learn about new markets and channel members (Handfield \& Nichols, 2004; Hult et al., 2004), and as a way to engage in corporate renewal when that renewal involves learning from supply-chain partners (Dess et al., 2003; Palmatier, Dant, Grewal, \& Evans, 2006). Acquisitions may also be a means by which a larger supply-chain member can place an option on a smaller firm pursuing new technology (McGrath, 2001). Indeed, larger firms often engage in acquisitions in order to ensure that they are able to appropriate the rents from new resources and new technology (Pisano, 1990). The key issue in examining acquisitions of global supply chain members is that some of the values are the interorganizational relationships that have been created by the key management team (KMT) of the acquired organization (Flint, 2004; Handfield \& Nichols, 2004; Stank, Keller, \& Closs, 2001). Relationship marketing has created a high level of interest in interorganizational relationships with 400 articles being published on the topic since 1990 in the marketing literature (Palmatier et al., 2006)

Examining acquisitions from this perspective has significant implications on the response of the acquiring firm vis-à-vis the acquired firm. Although earlier research has identified the acquisition process as critical to the overall success of the acquisition (Jemison \& Sitkin, 1986), we submit that this becomes even more critical in the context of acquisitions as a means of corporate venturing. In particular, we argue that the ability of the acquiring firm to maintain the active support of the key talent in the acquired firm is critical to the success of the corporate venturing. Because human assets cannot be owned like a piece of equipment or a technology license (Coff, 1997, 1999), the human capital of an organization is not bound to the company after the acquisition. They (the acquired firm's human assets) may decide to leave after the acquisition especially if they perceive that the acquiring firm is mistreating or else neglecting its responsibilities towards them. This perceived neglect often grows out of a violation of the psychological contract between the employing organization and the employees (Morrison \& Robinson, 1997; Rousseau, 1989).

The psychological contract represents the employees' beliefs about the reciprocal rights and obligations between them and the acquiring organization. After the acquisition, employees may feel that these obligations have been repudiated. In the end, if an organization acquiring a firm as part of its corporate venturing activity fails to embrace the new employees and to reestablish the psychological contract, defection may occur. This is of particular interest in acquisitions where relationships are central to the value of the management team (e.g., marketing relationships in supplychains) (Harvey \& Richey, 2001; Joshi, 1993).

Because important knowledge is often embedded in the human assets of an organization (Lepak \& Snell, 1999), the ability to learn through acquisitions within a corporate venturing context would tend to magnify the importance of the human assets in the acquired supply-chain organizations. With this in mind, we seek to identify first whether the retention of the key management team (KMT) in acquired firms as part of corporate venturing activity is associated with stronger post-acquisition performance in those units. Second, we seek to identify whether the development of psychological contract elements leads to greater retention of the key management team. Lastly, we seek to examine how the external environment affects the implementation of the psychological contract elements. Greater dynamism (e.g., interorganizational relationships) within a corporate venturing context, requires a need for greater human resource attention to the entire acquisition process (De Wulf, Odekerken-Schroder, \& Iacobucci, 2001; Wright et al., 2001).

Our theoretical contribution is focused on extending resource based theory by identifying how organizations engaging in corporate venturing through supply-chain acquisitions preserve the embedded value (e.g., critical human capital) of the acquisition. We begin to address issues concerning the coping mechanisms used by organizations to retain greater value when that value is derived from human assets (cf. Coff, 1997; Wright et al., 2001). If the psychological contract can be used as a device to retain critical inter-organizational talent and limit post-acquisition turnover, our results will have practical significance as well (Gruen, Summers, \& Acito, 2000).

This paper follows the logic of: first, target firm's key management team (KMT) retention and the subsequent effect of post-acquisition performance from a resource based view are explored. Second, contract theory and the development of psychological contracts and how they evolve between the target firm's KMT and the acquirer are examined. Third, hypotheses are developed to explain post acquisition performance, which is centered on the effects of KMT retention and psychological contract development on post acquisition performance. Fourth, the hypotheses in the sample of acquisitions are tested. Fifth, the results of the study are discussed.

\section{Key management team (KMT) ongoing value}

The resource based view of the firm suggests that organizations accumulate and develop a bundle of specialized resources that are both tangible vs. intangible and internal vs. external to the firm. These resources, when applied appropriately, should generate above average returns and can create a sustainable competitive advantage (Barney, 1986, 1991; Peteraf, 1993; Wernerfelt, 1984). When it is impossible to develop such human resources organically (internally), firms often will attempt to obtain these relational resources through acquisition (externally).

The focus of research in the resource based view is probably best restricted to those differences between organizations that competitors cannot (or do not) duplicate for whatever reasons, or that competitors cannot duplicate loosely enough to eliminate the advantage (Hunt \& Morgan, 1994; Palmatier et al., 2006). Due to inimitability and the dependent variable as competitive advantage, competitor's inability to duplicate successful (rare, non-substitutable, inimitable, and valuable) strategies will create a sustainable competitive advantage. Examples of these resources/assets are: key management team, brand names, in-house knowledge of technology, employment of skilled personnel, trade contacts, machinery, efficient procedures, and capital.

The resource based view offers that physical, human, and organizational resources are an organization's source of competitive advantage when they are valuable, rare, non-substitutable and inimitable (Barney, 1991). These resources can be modified as an organization's knowledge of markets, technologies, and consumer needs and attitudes are affected by external inputs (Penrose, 1959). The KMT has control over all organizational resources, human resources and physical assets to one degree or another (Goetz \& Scott, 1981). As new knowledge is developed or obtained, the KMT reacts to modify strategy. The KMT plus their expert knowledge (Lippman \& Rumelt, 1982) can be seen as a valuable, rare, non- 
substitutable and inimitable resource (Johnson, 1999). Knowledge based resources, such as the KMT and their experience, assist in the development of the organization's strategy, core competencies, and subsequently its value (Iacobucci \& Ostrom, 1996; Miller \& Shamsie, 1996).

Human resources are particularly valuable to any organization in developing a competitive advantage through relationship management in supply-chains (Lepak \& Snell, 1998). Human capital is one of the most important resources in a firm and top management team experience is one of the most sought after criteria when purchasing supply-chain members (Zacharakis \& Meyer, 2000). The resource based perspective has important implications for the importance of KMT, especially when "the productivity of superior resources depends upon the nature of their employment and the skill with which a strategy based on resource superiority is implemented" (Peteraf, 1993: p. 186). One of the implicit forms of resources is the relationship that is built between organizations to form the global supply chain. Personal relationships form the bedrock of relational marketing and are instrumental in the functioning of the global supply chain as well as critical in the on-going maintenance of the flow of goods and services in global supply chains (Lusch \& Brown, 1996).

Relationship marketing in global supply chains can be defined as networks or interactions between partners with the goal of a win/win outcome increasing relationship duration (Gummesson, 1996). In relationship marketing, asymmetrical relationships can exist but the dis-equilibrium moves the organization towards monopoly or dissolution (Gummesson, 1996). Typical constructs include: influence (supplier/buyer), cooperation, satisfaction, dependence, trust, reliability, honesty, benevolence, commitment, justice, culture and diligence (Anderson \& Narus, 1990; Doney, Cannon, \& Mullen, 1998; Dwyer, Schurr, \& Oh, 1987; Ganesan, 1994; Gummesson, 1996). Ultimately the contribution of the relationship marketing to the effective operation of global supply chains is that of understanding and collaboration between firms in the global supply chain (Gummesson, 1996; Iacobucci \& Ostrom, 1996). Such collaboration is governed by trust and contracting in global supply chain management.

Relationship development in global supply chain management flows through the stages of: (1) awareness; (2) exploration; (3) attraction; (4) communication/bargaining; (5) development of power; (6) development of norms; (7) development of expectations, expansion, commitment (level of inputs, durability/longevity and consistency/frequency) and; (8) dissolution (Dwyer et al., 1987). From these stages, working partnerships are defined. Research shows that in these partnerships, cooperation breeds trust that breeds more cooperation (Anderson \& Narus, 1996; Srinivasan \& Moorman, 2005). The Anderson and Narus model proposes that communication affects relative dependence, outcomes, and trust; trust is also affected by cooperation; influence and trust affect conflict; trust and conflict affect outcomes (Anderson \& Narus, 1996). According to this framework, there is little doubt pertaining to the importance of trust in relationship development and continuance (Gruen et al., 2000; Hennig-Thurau, Gwinner, \& Gremler, 2002). The question that is pertaining to relational marketing operations is do these relationships transfer? (Hibbard, Brunel, Dant, \& Icobucci, 2001)

A significant amount of new ventures in global supply chains is started by teams of individuals working in an interorganizational manner among the members of the global supply chain (Chandler, Honig, \& Wiklund, 2005). As these ventures mature, changes in the requirements for capabilities and competencies also evolve into organizational as well as personal relationships (Iacobucci \& Ostrom, 1996). Therefore, any key manager departures are more likely to have an impact on the performance of the global supply chain's performance (James \& Soref, 1981). For example, the stabilization of roles becomes formalized in venture growth and departures provide a functional anchor that helps to bind the relationship together after an acquisition (Chandler et al., 2005).

Supply chain management research suggests that collaboration instead of competition is emphasized (Vainio, 2005) and value creation is envisioned as the chief goal of multiple firms (Lee \& Cavusgil, 2006) developed over time by individuals. In supply chain value networks, firms that manage to integrate their actions through collaboration are often able to deliver significantly improved performance (Barratt, 2004; Stank, Keller, \& Daugherty 2001), and benefit yet further from closer relationships that foster dynamic opportunities for superior network performance (Blankenburg-Holm, Eriksson, \& Johanson, 1999). Although much of this research is based upon the unit analysis of firm level, and now researchers are focusing on the entire length of the supply chain as the unit of analysis, all the research acknowledges the importance of the individual to develop the trust and relationships necessary.

Managerial definitions of supply chain partnerships or value networks are very vague, such as "meeting of minds" (Ellram \& Hendrick, 1995), or focusing on the motives (Landeros, Reck, \& Plank 1995) and outcomes of the relationship rather than identifying specific attributes. Dependency between parties (Brennan, 1997) such as, information sharing, coordination of resource sharing (Whipple, Frankel, \& Daugherty, 2001), long-term orientation (Ganesan, 1996), as well as risks and rewards of the relationship (Ellram \& Hendrick, 1995) has been identified by scholars as key forms of dependence. Per social network theory, these relationships may not transfer if one of the individuals were to leave the firm after the acquisition.

One of the relational benefits inherent to supply chains is improvement in organizational social capital developed by individuals over the chain duration (Lanier, Wempe, \& Zacharia, 2010). Relational exchange norms and values such as role integrity, mutuality, solidarity, flexibility, bilateral information exchange, harmonious conflict resolution and long term orientation are shared between the partners, both individually and as a firm (Brown, Dev, \& Lee 2000). These norms contribute to the existing social capital of partners and have an impact on the firm level organizational social capital. Since social capital facilitates resource exchanges between partners (Adler \& Kwon, 2002; Gabbay \& Zuckerman, 1998) competitive advantage is now derived not between firms but from competition in supply chains (Harland, Caldwell, Power, \& Zheng, 2007). When individuals leave the firm where they have been the cornerstone of the relationship between two firms, the relationship may also become severed.

The KMT through their direction, strategy formulation, and management manipulates and develops the synergies among the organization's resources. For example, intangible assets complement tangible assets such as plant and equipment or market based assets such as customer/brand and channel relationships (Srivastava, Shervani, \& Fahey, 1998). However, organization resources are influenced by a variety of actions taken by management both in the rate of growth of the organization and in the direction of growth. Inimitability in human resource competencies is developed through unique historical paths maintaining often hidden interdependencies, particularly when inter-organizational relations are at the center of the value of the asset (Becker \& Huselid, 1998).

The complexity of the internal and external environment makes the KMT's strategic decision-making difficult and is influenced by their idiosyncratic situational contexts. Amit and Schoemaker (1993: p. 44) argue, "owing to uncertainty, complexity, and conflict (both in and outside the organization), different organizations will employ different strategic assets, without any one set being probably optimal or easily imitated". In essence, how the KMT employs the assets, affects the success of a strategy. As the KMT 
and their actions are very difficult to observe or imitate, the more successful the strategy the more sustainable will be a competitive advantage (Barney, 1986, 1991; Godfrey \& Hill, 1995).

In summary, the resource based view suggests that bundles of combinations of tangible and intangible resources within the organization can be a competitive advantage for organizations. As KMT controls the strategic disposition of these assets, and the accumulation and development of both the intangible and tangible assets, the KMT of a successful target firm could very well be the lynch-pin for continued competitive advantage.

$\mathbf{H}_{\mathbf{1}}$. There is a positive relationship between human capital in the form of KMT retention and post-acquisition performance of the acquired supply-chain firm.

\subsection{Psychological contract with KMT members}

It is argued that the KMT is central in the retention of the value of an acquisition in the supply chain when that acquisition is undertaken for corporate venturing purposes. The KMT maintains specific knowledge concerning the organization and its relationships in the inter-organizational environment and this knowledge is often tacit and therefore, not easily transferred to others. Additionally the resources and capabilities of the organization being acquired are often tied to the KMT (cf. Alvarez \& Busenitz, 2001). As a result, we argue that the ability to appropriate value from the acquisition is contingent on the retention of the KMT and this will likely be a key goal when acquisition is part of an organization's corporate venturing activities in supply-chains.

To understand the dynamics of KMT retention in an acquisition, it is essential to understand the formal and informal linkages of the target firm's KMT. The KMT has developed a formal relationship within its firm (concerning things such as salary and benefits) and informal inter-organizational relationships developed over time with supply-chain members and other external constituents. This informal relationship internally is manifested as a psychological contract and embodies such things as mutual expectations and core values. The target firm's KMT is bound to the firm through these formal and informal relationships. If the acquiring firm wishes to retain the KMT, we believe that the psychological contract must be developed or transferred.

In defining employment relationships, psychological contracts have become more important in understanding the retention and motivation of key employees (Turnley, Bolino, Lester, \& Bloodgood, 2004). Mutual obligations between the firm and the KMT which have developed over time are entwined in psychological contracts that go beyond written employment contracts or explicit job duties. Literature has suggested that when the psychological contract has been breached by the firm, that the employees' attitudes and behaviors change for the worse and as a result produce negative outcomes, such as quitting (Goetz \& Scott, 1981). During an acquisition new goals and norms will be established, effectively transforming employees' roles and obligations affecting the prior psychological contract between the KMT and the firm. As such, either a new psychological contract needs to be developed or the previous one transferred to retain the KMT.

To understand perceived employment obligations, one needs to consider the social phenomena in which they are entwined and the acquisition context brings great uncertainty (Anderson \& Narus, 1996). As psychological contracts are defined as a person's mutual obligations in an employment exchange relationship, the acquiring firm must quickly identify the KMT and discuss/develop these mutual long-term goals that are not restricted to purely economic terms but to also loyalty in exchange for security and growth within the new organization (Raja, Johns, \& Ntalianis, 2004). This is of particular importance when dealing with managers with key external inter-organizational relationships (i.e., key accounts or key channel relationships).

Accordingly, it can be argued that the acquiring firm's actions in regard to the psychological contract development with the target firm's KMT will directly affect retention of the KMT (Joshi, 1993). As the KMT has the power to leave the firm, and is valuable enough to have the opportunities to do so, the acquiring firm will have to develop a relationship that is mutually acceptable. If the acquiring firm does not develop a psychological contract through mutual goal development, or formulation of agreeable norms acceptable to the KMT, then the KMT is apt to leave.

$\mathbf{H}_{2}$. There is a positive relationship between the development of the psychological contract and KMT retention after the acquisition of the target firm.

\subsection{Market turbulence during global acquisitions}

The ability to develop a psychological contract with the KMT will also be affected by the characteristics of the market environment. In particular, the managers preexisting interorganizational relationships will influence relational interaction and contact development. Market turbulence varies in intensity and the ability and necessity to develop psychological contracts will vary as well. The type of market affects how an organization's human resources are organized, employed and subsequently integrated by the KMT managers (Barney, 1986, 1988; Dierickx \& Cool, 1989; Wernerfelt, 1984). Additionally, the market type also affects the embedded knowledge base of the firm. Knowledge often becomes the most strategically significant resource of the organization because it allows for the development of dynamic capabilities as the environment becomes increasingly turbulent (Grant, 1996; Quinn, 1992).

From an organizational theory perspective, market turbulence (also called market uncertainty, environmental uncertainty, industry turbulence, and industry dynamics) significantly impacts organizational structure and performance (Lu \& Yang, 2004). For example, cross-functional cooperation (Griffin \& Hauser, 1996), and research and development and marketing personnel need to strengthen cooperative ties for competitive advantage in highly competitive environments. Market turbulence relates to the rate of unpredictable change in a firm's environment and its effect is to hinder the ability of managers to predict future events affecting the firm (Child, 1972). High levels of market turbulence place great demands upon the KMT as routine solutions are not acceptable (Wiersema \& Bantel, 1993). Therefore, in firms in industries characterized by high levels of market turbulence, KMTs will need to be proactive in the exploration of new niches and resources (Lumpkin \& Dess, 2001). Successful firms in these industry environments tend to have KMTs that make decisions characterized by speed and comprehensiveness (Eisenhardt, 1989). As demands are constantly shifting, opportunities for these managers will become abundant and performance should be better in these firms with such a fit between orientation and industry environment (Wiklund \& Shepherd, 2005).

Market turbulence plays a role in acquisitions because it impacts the optimal level of integration of supply-chain members. Under- or over-integration can result in failure to create value, or result in value destruction such as the loss of key relationships in the value-chain (Pablo, 1994). The environment of a market will influence the organizational and strategic routines, by which firms achieve new resource reconfigurations (relationships) as markets emerge, collide, split, evolve, and die (Eisenhardt \& Martin, 2000). Also, organizations have time-based interdependencies between their resources and the inter-organizational environment which 


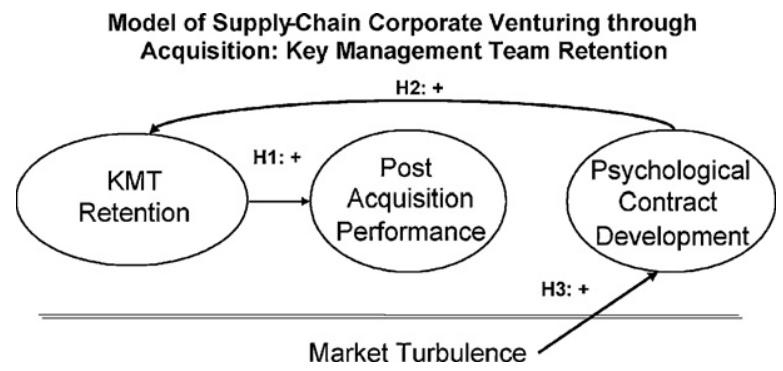

Fig. 1. Model of supply-chain corporate venturing through acquisition: key management team retention.

are critical aspects of the development of strategic options in the supply-chain.

Because change is a critical component of the highly turbulent market, organizational knowledge embedded within the KMT takes on increased importance because this knowledge forms the basis for absorptive capacity and dynamic capabilities (Brown \& Eisenhardt, 1997; Ireland \& Hitt, 1999) (see Fig. 1). Accordingly, we argue that psychological contract development is essential in intense markets. Mutual understanding over roles, handling of unexpected events, and management of the target firm after acquisition in such a dynamic environment will rely upon psychological contract development.

$\mathbf{H}_{3}$. There is a positive relationship between market turbulence and need for psychological contract development particularly when inter-organizational relations are central to the value of the acquisition.

\subsection{Methodology}

\subsubsection{Data collection}

Several elements must be considered before conducting empirical tests on the proposed relationships in our model: the model itself does not lend itself to a study using secondary data, therefore developing/pre-testing the items and questionnaire, identification of sample, response bias, common method variance and scale development all need to be reviewed. Due to the highly perceptual nature of data related to target firm post-acquisition performance and also in regard to the psychological contract development, a survey method of collecting data is most appropriate. For most firms, acquisition of financial performance information is usually consolidated if reported publicly, so specific acquisition performance data would not be available. Further, the majority of the acquisitions under examination are quite small. To ascertain post-acquisition performance of the acquired firm, perceptual data were required. Insider informants have been used extensively in strategy research (e.g., Frederickson, 1984).

We initially prepared a draft questionnaire with items to test the variables. We obtained input on these preliminary items from an expert panel of M\&A professionals from different industries, as well as from respected academics. The expert panel was composed of five academics terminally qualified with a focus in M\&A research, one partner from Ernst and Young, one Senior Vice President from GE in charge of their M\&A department, one senior executive for the US in charge of logistics for a $\$ 10$ billion firm, and $1 \mathrm{CFO}$ of Europe in charge of M\&A.

A pilot study was performed with a small sample of business professionals that have participated in acquisitions. Fifteen people reviewed the preliminary items. Three were from Price-Waterhouse/Coopers, three were international mergers and acquisitions managers, six were top managers, and three were academics. We administered the pilot version of the questionnaire to these M\&A professionals. After the pilot was administered, we analyzed the data. During this pilot study we had asked the participants to make suggestions in regard to confusing questions, or any comments in general. We made changes in the instrument where we deemed necessary based on this feedback. We administered the pilot version of the questionnaire to these M\&A professionals. The pilot data were not included in the final analysis. Although not included in these research findings, we noted that a large percentage of the acquisitions had pre-acquisition performance higher in comparison to referent others in their industry. This is in line with the pilot study participants' suggestions, the expert panel advice, and the resource based view, as firms in a value chain would acquire firms with rare, inimitable and valuable assets which would suggest they are performing well in general.

\subsubsection{Sample}

The individuals we surveyed came from an Ernst and Young Inc. database of top executives who have bought supply-chain firms within the past year. The database contained 807 names. Examples of the titles of the individuals that were sent the surveys were Vice Presidents (110), Senior VPs (23), CEOs (24), CFOs (25), and Directors (49). These are senior managers who have been directly involved in a recent acquisition and are aware of the postacquisition performance of the acquired firm. After eliminating those that were either no longer at that address, "return to sender", or their office notified us they were no longer with the firm, or deceased, we had 610 possible respondents. We received a sample of 102 responses although only 99 were complete for a response rate of $17 \%$. Of the responses, answers to the questions "Was the acquisition an important supplier?" and "Was the acquisition an important customer?" lead to approximately 92 of the acquisitions either directly being a "current" suppliers (45) or customers (47).

The response rate for surveys of senior management is typically very low, so we were pleased with the number of responses obtained as it is consistent with similar surveys (cf., Hambrick, Geletkancyz, \& Fredrickson, 1993; Weaver, Trevino, \& Cochrane 1999). Industries represented in the data were from 72 different areas (see Table 5). The recipients of the survey were executives who were involved with acquisitions globally, although their mailing addresses, home and office, were within the US. As the US has nearly $30 \%$ of the largest global companies (per Forbes Fortune 500 ), much of the international acquisition activity occurs through US firms buying overseas.

\section{Measures (see Appendix A for details of items used)}

\subsection{Dependent variable}

Performance: scholars typically use a variety of measures to measure the multidimensional construct of performance (Edelman, Brush, \& Manolova, 2005). We focused on three key areas of acquisition performance: financial performance (four items), goal attainment (four items), and employee performance (two items). These three measures represent financial and non-financial outcomes. A comparative method is more effective in eliciting responses than asking respondents directly to provide exact numbers for acquisition performance (Lau \& Ngo, 2001; Tomaskovic-Devey, Leiter, \& Thompson, 1994). We asked respondents to respond to perceived performance using a 7-point Likert scale (higher scores representing higher performance) on each of the three areas using ten items to obtain a scaled performance metric. The scale was developed by utilizing pre-existing measures developed by Lau and Ngo (2001) and Cannella and Hambrick (1993) and adapting them through suggestions from our expert panel plus through pre-testing. The Cronbach's alpha for the 10 items was $\alpha=0.94$. 


\subsection{Independent variables}

Psychological contract: measures the extent to which the psychological contract of the relationship was transferred or developed. For psychological contract measurement, we adapted a pre-existing scale (Lusch \& Brown, 1996) with five separate items. The measures focused on psychological contracting over roles and psychological contracting over the handling of unexpected events as well as the mutual understanding of roles and responsibilities. We used a 7-point Likert scale to measure these areas of the psychological contract and obtained an overall Cronbach's alpha of $\alpha=0.86$ for the five items.

KMT retention: is measured with four items and identifies the proportion of executives that were retained. Similar to Cannella and Hambrick (1993), the perceived volume of valuable executives retained as well as whether the acquired KMT remained intact. As suggested by pre-testing responses and from the expert panel, reviewing the sheer number of executives retained for small to medium sized firms does not provide a full picture. Although we argue that the KMT is valuable it is also true that there are those individuals in smaller firms who may be (for example) relatives with an executive title (or similar situations), but of no value. Therefore we explore both, the number of executives retained, and whether the valuable executives were retained. Again, we used a 7point Likert scale to measure retention and obtained an overall Cronbach's alpha of $\alpha=0.967$ on the four items.

Market turbulence environmental: instability plays an important role in influencing decision effectiveness (Dean \& Sharfman, 1996). Most researchers agree that the concept of industry competitive dynamics is composed of multiple dimensions. We asked the managers to identify the industry they are in (e.g., Biotech, hightech, and transportation) (Table 1). Market turbulence was measured through two measures: munificence and dynamism similar to previous research (Ensley, Pearce, \& Hmieleski, 2006, see also Keats \& Hitt, 1988). Munificence is the capability or the ability of the environment to sustain growth. Dynamism is the stability or instability and the rate or degree of environmental change (Dess \& Beard, 1984). Munificence was calculated using a five-year growth in net sales for each industry (1998, 1999, 2000, 2001, and 2002).

Using annual figures across all firms in each relevant industry, the natural logarithms were utilized in a time series approach from Standard and Poor's Industry Surveys (11-13-2003). Time served as the independent variable. The growth measure of each was the antilog of the regression slope coefficient. The result is a smoothed measure of the average growth rate over the period. Instability reflected five year patterns of instability in the dominant industry. The measures were antilogs of the standard error of each regression slope coefficient from the growth equations described in the munificence measure. Thus to be consistent with the arguments of Dess and Beard (1984) and Tosi, Aldag, and Storey (1973) the indicators capture true discontinuities in the task environment and allow similar scores for task environments that present similar patterns but at different base levels of magnitude.

Control variables: size differences between acquiring and acquired firms may influence acquisition performance (Kusewitt, 1995). We included this as a control in our analyses. Increases in organizational size add complexity with its attendant increases in structural elaboration and formalized systems for planning, control, and resource allocation (Quinn \& Cameron, 1983). Increases in organizational size can create progressively stronger resistance to fundamental change (Tushman \& Romanelli, 1985). Some researchers suggest that the smaller an acquired firm is relative to an acquiring firm, the greater an acquired executive's propensity to depart (Hambrick \& Cannella, 1993). Consistent with previous work in the acquisition literature, we calculated size by dividing the sales of the acquired firm before acquisition by the sales of the acquiring firm (Hambrick \& Cannella, 1993).

Our second control variable was the method by which the firm was purchased. From the acquirer's perspective, they can use their cash holdings, increase their debt by borrowing, and sell more equity through shares of stock, or a combination of these. As our research focus is on the target firm's KMT including their retention and value to post-acquisition performance, we are concerned with the form of payment for the acquisition because a cash purchase may unduly enrich the target firm KMT (assuming they are stock holders) who may then wish to exit. Therefore we controlled for either receipt of cash ("1") or other ("2").

We also controlled for the ownership structure of the target firm (i.e., privately owned, publicly owned with dispersed stockholders, or publicly owned with few majority stockholders). Privately owned firms will typically be managed by an owner who is also a member of the KMT. Purchasing a privately owned firm may or may not suggest that the owner is either retiring or going to pursue other interests. Consistent with the RBV, the owner may only be seeking resources from the acquiring firm in which to continue and be more successful. A publicly owned firm with diverse investors will be managed by a KMT of experts. We controlled for whether the acquired firm was a privately owned ("1") or other ("2").

Managers that are familiar with mergers and acquisitions are typically KMT who may not readily respond to surveys. We used extrapolation methods to examine non-response bias. Extrapolation methods are based on the assumption that subjects who respond less readily (late responders) are more like nonrespondents than are early responders. The most common type of extrapolation is carried over successive waves of a questionnaire (Armstrong \& Overton, 1977). Wave analysis employing MANOVA was used to check for non-response bias examining selected scale items from each construct (Armstrong \& Overton, 1977). Each of the major survey waves was counted as a separate wave, for a total of three waves. Wave analysis, in the form of MANOVA, was performed covering all relevant variables and found no significant differences between each wave that would indicate the possibility of non-response bias.

Key informant methodology has some significant drawbacks in the forms of informant bias and random error. Since our sample used key informants that occupied roles that make them knowledgeable about the issues being researched and were able and willing to communicate with the first author, we aver that key informant bias is not a major consideration. Retrospective reports in regard to perceptions have been researched (Golden, 1992; Huber \& Power, 1985) utilizing executive's retrospective accounts to identify firm strategy (Boeker, 1989), planning processes (Eisenhardt \& Bourgeois, 1988) and strategic and organizational change (Eisenhardt \& Schoonhoven, 1990). Other research suggests sole informants at high levels such as CEO may actually increase the validity, or confidence in their report (Sharfman, 1998). More recent research suggests that retrospective reports are accurate and an effective technique for management research (Golden, 1992).

\subsection{Analysis}

To assess multivariate and univariate normality analyses of skewness, kurtosis, and outliers were performed using Q-Q (P-P) plots and standard tests for each indicator. Reviews of the skewness and kurtosis statistics suggest that no transformations were required as all the skewness and kurtosis numbers fall below 1.96 which corresponds to a 0.05 error level (Hair, Anderson, Tatham, \& Black, 1998). We utilized Harman's one factor test to assess the degree of common method variance due to the fact that the data all came from the same survey. The results of this procedure suggest 
Table 1

Means, standard deviation and correlation among all variables.

\begin{tabular}{|c|c|c|c|c|c|c|c|c|}
\hline & Mean & $\begin{array}{l}\text { Standard } \\
\text { deviation }\end{array}$ & 1 & 2 & 3 & 4 & 5 & 6 \\
\hline (1) Performance & 4.66 & 1.43 & & & & & & \\
\hline (2) Retention & 4.40 & 1.96 & 0.40 & & & & & \\
\hline (3) Psychological contract & 4.85 & 1.23 & 0.45 & 0.55 & & & & \\
\hline (4) Environmental turbulence & 2.06 & 0.78 & 0.06 & 0.12 & 0.19 & & & \\
\hline (5) Size & 0.31 & 0.92 & -0.17 & 0.07 & -0.15 & -0.10 & & \\
\hline (6) Ownership ${ }^{a}$ & 1.60 & 0.49 & -0.05 & 0.05 & 0.04 & 0.27 & 0.10 & \\
\hline (7) How purchased ${ }^{\mathrm{a}}$ & 1.49 & 0.50 & -0.05 & -0.08 & -0.01 & -0.09 & 0.20 & -0.12 \\
\hline
\end{tabular}

Correlation $>0.36$ significant at $p<.01$, correlation $>0.20$ significant at $p<.05$.

a Spearman rank correlation with ordinal data.

that a single factor did not emerge nor one general factor account for the majority of variance (e.g., Greene \& Organ, 1973).

For construct validity, we performed exploratory factor analysis to see if a unidimensional solution came out of the exploratory analysis. For each of our independent and dependent variables we found that each construct's items were all significantly correlated $(p<.001)$ in accordance with the Bartlett test of sphericity, Cronbach's alpha and the Kaiser-Meyer-Olkin measure of sampling adequacy (MSA) suggested high intercorrelation among the related variables of each construct.

\subsection{Results}

Table 1 presents the means, standard deviations and correlations for our variables. Table 2 presents the results of the testing of the hypotheses (Tables 3 and 4).

To examine the hypotheses, we used hierarchal linear regression with controls entered first followed by the independent variable. Hypothesis 1 examined the relationship between retention and

Table 2

The impact of retention of the KMT on performance.

\begin{tabular}{llc}
\hline \multicolumn{1}{c}{ Dependent variable } & & \\
\hline Performance & Controls & Retention \\
\hline Size of acquisition & $-0.16(1.61)$ & $-0.19^{*}(2.07)$ \\
Cash used in purchase & $-0.06(0.57)$ & $-0.03(0.32)$ \\
Privately owned & $-0.08(0.76)$ & $-0.09(0.94)$ \\
& & \\
$\quad$ prior to acquisition & & $0.42^{* *}(4.59)$ \\
Retention of KMT & 0.035 & 208 \\
$R^{2}$ & 1.20 & 6.35 \\
$F$-statistic & 0.035 & 0.137 \\
$R^{2}$ & 1.20 & $21.09^{* *}$ \\
$F$-statistic for change & & 0.20
\end{tabular}

$N=99$. Standardized coefficients reported. $T$-Statistics reported in parentheses.

${ }^{*} p<.05$.

$p<.01$.

Table 3

The impact of psychological contract development on KMT retention.

\begin{tabular}{lcc}
\hline \multicolumn{1}{c}{ Dependent variable } & & \\
\hline KMT retention & Controls & $\begin{array}{l}\text { Psychological } \\
\text { contract development }\end{array}$ \\
\hline Size of acquisition & $0.07(0.68)$ & $0.15(1.80)$ \\
Cash used in purchase & $-0.07(0.66)$ & $-0.07(0.81)$ \\
Privately owned prior to acquisition & $0.02(0.22)$ & $0.01(0.15)$ \\
Psychological & & $0.57^{* *}(6.75)$ \\
$\quad$ contract development & & \\
$R^{2}$ & 0.011 & 0.331 \\
$F$-statistic & 0.342 & 11.77 \\
$R^{2}$ & 0.011 & 0.321 \\
$F$-statistic for change & 0.342 & $45.58^{* *}$ \\
\hline
\end{tabular}

$N=99$. Standardized coefficients reported. $T$-Statistics reported in parentheses.

$p<.01$. post-acquisition performance. The coefficient for this variable was positive and significant $(p<.001)$. Accordingly, we find that postacquisition retention of the KMT is positively associated with performance in the business unit. Therefore, $\mathrm{H}_{1}$ is supported.

We wanted to test whether the KMT is a valuable resource from a RBV perspective and whether their retention facilitated greater performance post-acquisition. Contrarily, the market for corporate control suggests that the firm was bought because it was underperforming and brought in new management, thus not retaining the KMT. These two theoretical frameworks are not contradictory. During the development of the market for corporate control literature, the time frame was during the years of conglomerate building, staid industries with secondary samples from the US, while our research explores the global dynamic environment where the majority of firms are acquiring to compete globally and are not seeking underperforming firms, but successful ones that when combined create even greater success. These observations are in agreement with current research and those opinions of our expert panel.

Hypothesis 2 examined the relationship between psychological contract development and retention. The coefficient for psychological contract development was positive and significant $(p<.001)$ thereby supporting hypothesis 2 . When the acquiring organization puts greater effort into developing the psychological contract between the KMT of the acquired unit and the corporation, a greater portion of the KMT stays after the acquisition. This has implications for at the very least due diligence, hostile acquisitions and acquisition negotiations. During the due diligence, the acquiring firm should begin the psychological contract development and not just make this a data collection effort by outside agencies and accountants and continue through to negotiations and post-acquisition monitoring. If the KMT is a valuable asset, hostile takeovers will not have the impetus for psychological contract development, thus loss of the KMT.

Hypothesis 3 examined how environmental dynamism affected the development of the psychological contract. We believed that greater dynamism would prompt the acquiring organization to put

Table 4

The impact of environmental turbulence on psychological contract development.

\begin{tabular}{lcc}
\hline \multicolumn{1}{c}{ Dependent variable } & & \\
\hline Psychological & Controls & $\begin{array}{l}\text { Environmental } \\
\text { turbulence }\end{array}$ \\
contract development & & $-0.123(1.23)$ \\
\hline Size of acquisition & $-0.15(1.46)$ & $0.021(0.21)$ \\
Cash used in purchase & $0.00(0.02)$ & $-0.036(0.347)$ \\
Privately owned prior to acquisition & $0.02(0.17)$ & $0.222(2.16)$ \\
Environmental turbulence & & 0.067 \\
$R^{2}$ & 0.022 & 1.71 \\
$F$-statistic & 0.706 & 0.046 \\
$R^{2}$ & 0.022 & $4.66^{*}$ \\
$F$-statistic for change & 0.71 &
\end{tabular}

$N=99$. Standardized coefficients reported. $T$-Statistics reported in parentheses. $p<.05$. 
Table 5

List of industry types reported by respondents.

\begin{tabular}{|c|c|c|c|c|c|}
\hline Apparel & 1 & Energy & 1 & Logistics & 1 \\
\hline Automotive & 2 & Energy Holding Co. & 1 & Manufacturing & 6 \\
\hline B2B e-commerce software & 1 & Engineering services & 2 & Marketing services & 1 \\
\hline Bakery manufacturer & 1 & Federal consulting & 1 & Mechanical contractor & 1 \\
\hline Banking & 1 & Fiber optics & 1 & Medical software & 1 \\
\hline Billing software & 1 & Financial & 1 & Military contracting & 1 \\
\hline Biopharmaceutical & 2 & Financial investments & 1 & Mortgage banker & 1 \\
\hline Biotech & 2 & Financial services & 3 & Mortgage banking & 1 \\
\hline Broadcasting & 1 & Funeral & 2 & Office equipment distribution & 1 \\
\hline Business consulting & 1 & Gas and oil & 1 & Online marketplace & 1 \\
\hline Business services & 1 & Government contracting & 1 & Outsourcing services & 1 \\
\hline Chemical & 1 & Government contracting - IT & 1 & Professional services & 1 \\
\hline Chemical production & 1 & Government IT services & 1 & Retail & 3 \\
\hline Collection & 1 & Healthcare & 2 & Savings and loan & 1 \\
\hline Commercial Bank & 1 & Healthcare products & 1 & Security services & 1 \\
\hline Communications and technology & 1 & High Tech & 1 & Software & 3 \\
\hline Communications solutions & 1 & Industrial instruments & 1 & Storage software & 1 \\
\hline Computer sales & 1 & Information technology & 3 & Technology-based business solutions & 1 \\
\hline Computer software & 1 & Insurance & 1 & Telecom & 7 \\
\hline Computing products & 1 & Internet & 1 & Telecom consulting & 1 \\
\hline Construction & 4 & Internet billing & 1 & Title insurance & 1 \\
\hline Defense & 2 & IT services & 2 & Transportation & 2 \\
\hline Direct broadcast satellite & 1 & Lawn and garden products & 1 & Voice and data communications & 1 \\
\hline dmv checks & 1 & Legal outsourcing & 1 & & \\
\hline
\end{tabular}

greater effort into developing the psychological contract in order to ensure greater retention of the KMT. We argued that environmental dynamism is associated with increased competition - and fast competitors. Significant KMT turnover would prove deleterious because it would slow the reaction of the business unit to competitive pressures. Thus, we hypothesized a positive relationship between environmental dynamism and psychological contract development. The coefficient for the industry dynamic variable is significant $(p<.05)$ in support of Hypothesis 3 .

In the global marketplace where the supply chain and management of the supply chain are now considered important to be competitive, firms are integrating forward and backward to create complementary strengths. Although outsourcing, off shoring, etc. are occurring, many firms are still acquiring to strengthen and leverage their competencies globally. Thus the dynamic global environment in which all firms are competing will require the development of the psychological contract, especially in the hypercompetitive industries where products, services, customer needs are constantly changing and the supply management becomes even more critical (Table 1 ).

\section{Discussion and conclusion}

Acquisitions continue to be an important activity in the 21st century. Although they may serve an important function within a corporate venturing context, the ability to derive value from these acquisitions is often dependent on retaining the human capital of the key supply-chain management team. However, scholars are beginning to recognize the difficulty of realizing value when it is embedded in human assets (Coff, 1997). These actors are not constrained by organizational boundaries and care must be taken to gain their confidence and support after their organization is acquired. Our analysis reveals that development of the psychological contract in terms of establishing mutual understanding concerning expected roles and responsibilities as well as expectations concerning roles and responsibilities for dealing with unexpected events facing the organization aids in retention after the acquisition. This seems rather intuitive but is important for extending our understanding of acquisition performance from a resource based view.

Whereas most research examining post-acquisition performance has focused on corporate parent performance, we have focused on the perceived performance of the acquired organization. We have done this since our focus has been on the key management team of the acquired unit. Although perceptual measures suffer from limitations, the ability to obtain objective verifiable performance data is virtually impossible. In our study we found that greater retention is associated with superior performance within the business after acquisition. This too is rather intuitive especially since the majority of the acquisitions under consideration are much smaller than the mega-deals discussed in the public arena. Indeed, we find that larger relative acquisitions in our sample perform worse overall when retention is entered into the regression equation which would indicate potential problems with integrative efforts. We find that the relative size of the acquisition is also negatively related to the development of the psychological contract in support of this view.

Importantly, we find that market turbulence is positively related to the development of the psychological contract as hypothesized. Again, we believe that this is rather intuitive since environmental dynamism enhances the value of the key personnel inter-organization knowledge base and relationships. If this knowledge and personal contacts are resident in the human assets (e.g., key inter-organizational managers), then it makes sense that the acquiring organization would seek to establish the psychological contract as soon as possible as a means to retain the key management team with the inter-organizational contacts (Anderson \& Narus, 1996; Hunt \& Morgan, 1994; Palmatier et al., 2006).

We believe that an excellent opportunity exists to examine how the psychological contract affects spun-off units. Although spinoffs typically aid the corporation casting-off the business (Markides, 1992), the performance of the organizations spun-off is less clear (Daley, Mehrotra, \& Sviakuma, 1997). Indeed, Woo, Willard, and Daellenbach (1992) find no improved performance among spin-offs in terms of ROA, market to book, or sales growth. We suspect that in many cases the psychological contract may have already been violated for those spun off units particularly if the corporate parent has experienced performance problems before the spinoff. Examining retention after spinoffs is thus an interesting area of focus and may allow for the collection of verifiable performance data although perceptual data would still be needed to measure psychological contract perceptions.

The theoretical contribution of this research has implications for both the resource based view and the literature on psychological contracts. The dominant theoretical foundation for acquisitions was either agency theory where top managers were purchasing other firms as a portfolio to hedge their risk, or the market for corporate 
control where firms were seeking underperforming firms and after purchase replacing the KMT with their own managers. Both of these theories do continue to have explanatory power, but RBV is now becoming validated through research and the rare, valuable and inimitable assets in the "black box" of a firm are being explored. In a global supply chain where a successful firm is purchased for their competencies, the KMT will need to be retained to assist in leveraging of competencies. As the resource based view focuses on assets that are inimitable, acquisition may be the only alternative and the success in retaining the KMT will be a key factor.

This research also extends the psychological contract literature building on both the normative contracting literature in regard to supply chain relationships and psychological contracts. We have combined both streams of literature to explain the successful retention of the KMT after acquisition. The importance of retaining the KMT through the development of psychological contracts is apparent as post-acquisition performance is greater when retention of the KMT occurs.

\subsection{Managerial relevance}

This research has many lessons for practitioners in regard to the global supply chain KMT, acquisitions, and the process of acquiring. Although many firms continue to outsource, many other firms are still involved in acquiring firms within their global supply chain to leverage competencies and acquire new ones that may be country specific, product specific, necessary for control purposes, etc. Our research suggests that due to the KMT's role based on obtaining and coordinating resources, developing and implementing strategy, and the development of internal and external knowledge and networks, the KMT should be retained. This viewpoint is from the resource based view that the reason for the acquisition is to acquire rare, valuable and inimitable resources.

Past research suggests that often top managers leave the firm after acquisition because the psychological contract that was developed before acquisition between the KMT and firm is not transferable to the acquiring firm. There are several major implications to practitioners from our research. The KMT may not be motivated to remain after acquisition only by new monetary contracts but by the relationship development that is necessary for a psychological contract to be effective, which becomes more daunting depending upon the global nature of the supply chain and the local culture. As such, the development of the psychological contract should be initiated early in the acquisition process.

\section{Appendix A}

\section{KMT Retention:}

Most of the KMT members of the acquisition remained with our organization after purchase.

The KMT stayed generally intact after acquisition.

We retained the most valuable members of the KMT of the acquired organization.

Currently, what percentage of the KMT of the acquisition is still with your firm?

\section{Current Performance:}

The employees of the acquired organization are good workers

The acquisition has met the strategic goals we set

The Acquisition's net profit is smaller than anticipated

The price we paid for the acquisition was valued too high relative to the benefits received.

The acquisition will meet expected strategic goals.

The Acquired Firm fits into our overall strategy

Our organization is pleased with the talent of the acquired organization's employees. The valuation of the acquisition represented its true worth.

The financial performance of the acquired firm is much less than anticipated.

\section{Environmental Turbulence:}

In what industry was the acquisition made? (ex. retail, steel, biotech, transportation, etc.)

In what industry is your firm? (ex. retail, steel, biotech, transportation, etc.)

Then calculated based upon Munificence, Volatility and Complexity.

\section{Psychological Contract:}

We have a mutual understanding of how the TMT of the acquired organization will act in case of a major, unanticipated event.

In dealing with the TMT of the acquired organization, we have a mutual understanding of each of our roles

In dealing with the TMT of the acquired organization, we have a mutual understanding concerning remedies for performance failure

The TMT team of the acquisition requires extensive supervision.

During negotiations we developed a relationship with the TMT of the acquired organization. 
Size:

Approximately how large is your firm (i.e., the acquiring firm) in gross revenues?

Approximately how large was the Acquisition in gross revenues?

How Purchased:

Please indicate how your firm paid for the acquisition:
All cash
All Stock
All debt
Combination

\section{If your firm used a combination method, please indicate the percentage of each type of} financing used:

$\begin{array}{lr}\text { Cash } & \% \\ \text { Stock } & \% \\ \text { Debt } & \%\end{array}$

\section{Ownership Structure:}

\section{Which of the following best describes the ownership structure of the Acquisition, prior to}

Purchase?

Division or operating unit of another firm,

Privately owned

Independent public firm with a few significant stock holders

Independent public firm with dispersed ownership

\section{References}

Alvarez, S. A., \& Busenitz, L. W. (2001). The entrepreneurship of resource-based theory. Journal of Management, 27: 755-775.

Adler, P. S., \& Kwon, S. W. (2002). Social capital: Prospects for a new concept. Academy of Management Review, 27(1): 17-40.

Amit, R., \& Schoemaker, P. J. (1993). Strategic assets and organizational rent. Strategic Management Journal, 14: 33-46.

Anderson, E., \& Narus, J. (1996). Rethinking distribution: Adaptive channels. Harvard Business Review, 74(July-August): 112-122.

Anderson, J. C., \& Narus, J. A. (1990). A model of distributor firm and manufacturer firm working partnerships. Journal of Marketing, 54(1): 42-58.

Armstrong, J. S., \& Overton, T. S. (1977). Estimating non-response bias in mail surveys. Journal of Marketing Research, 14(3): 396-412.

Barney, J. (1986). Strategic factor markets: Expectations, luck and business strategy. Management Science, 42: 1231-1241.

Barney, J. (1988). Returns to bidding firms in mergers and acquisitions: Reconsidering the relatedness hypothesis. Strategic Management Journal, 9(1): 71-78.

Barney, J. (1991). Organization resources and sustained competitive advantage. Journal of Management, 17: 121-154.

Barratt, M. (2004). Understanding the meaning of collaboration in the supply chain. Supply Chain Management: An International Journal, 9(1): 30-42.

Becker, B. E., \& Huselid, M. A. (1998). High performance work systems and organization performance: A synthesis of research and managerial applications. Research in Personnel and Human Resources Management, 16: 53-101.

Blankenburg-Holm, D., Eriksson, K., \& Johanson, J. (1999). Creating value through mutual commitment to business network relationships. Strategic Management Journal, 20: 467-486.

Boeker, W. (1989). Strategic change: The effects of founding and history. Academy of Management Journal, 32: 489-515.

Brennan, R. (1997). Buyer-supplier partnering in British industry: The automotive and telecommunications sectors. Journal of Marketing Management, 13(8): 759-775.

Brown, J. R., Dev, C. S., \& Lee, D. (2000). Managing market channel opportunism: The efficacy of alternate governance mechanisms. Journal of Marketing, 64: 51-65.

Brown, S. L., \& Eisenhardt, K. M. (1997). The art of continuous change: Linking complexity theory and time-paced evolution in relentlessly shifting organizations. Administrative Science Quarterly, 42(1): 1-35.

Busenitz, L. W., Hoskisson, R. E., Arthurs, J. D., \& Hansen, M. H. (2006). Rent appropriation and choice of entry mode in corporate entrepreneurship. Working paper. University of Oklahoma.

Cannella, A., \& Hambrick, D. C. (1993). Effects of executive departures on the performance of acquired organizations. Strategic Management Journal, 14: 137-152.

Chandler, G. N., Honig, B., \& Wiklund, J. (2005). Antecedents, moderators, and performance consequences of membership change in new venture teams. Journal of Business Venturing, 20: 705-725.
Chang, S. J. (1996). An evolutionary perspective on diversification and corporate restructuring: Entry, exit, and economic performance during 1981-1989. Strategic Management Journal, 17: 587-611.

Child, J. (1972). Organization structure, environment, and performance: The role of strategic choice. Sociology, 6: 2-22.

Coff, R. W. (1997). Human assets and management dilemmas: Coping with hazards on the road to resource-based theory. Academy of Management Review, 22: 374 402.

Coff, R. W. (1999). When competitive advantage doesn't lead to performance: The resource-based view and stakeholder bargaining power. Organization Science, 10(2): 119-133.

Daley, L., Mehrotra, V., \& Sivakumar, R. (1997). Corporate focus and value creation. Evidence from Spinoffs. Journal of Financial Economics, 45: 257-281.

De Wulf, K., Odekerken-Schröder, G., \& Iacobucci, D. (2001). Investments in consumer relationships: A cross-country and cross-industry exploration. Journal of Marketing 65(October): 33-50.

Dean, J., \& Sharfman, M. (1996). Does decision process matter? A study of strategic decision-making effectiveness. Academy of Management Journal, 39(2): 368-397.

Dess, G., \& Beard, D. (1984). Dimensions of organizational task environments. Admin istrative Science Quarterly, 29(1): 52-67.

Dess, G. G., Ireland, R. D., Zahra, S. A., Floyd, S. W., Janney, J. J., \& Lane, P. J. (2003). Emerging issues in corporate entrepreneurship. Journal of Management, 29: 351378.

Dierickx, J., \& Cool, K. (1989). Asset stock accumulation and sustainability of competitive advantage. Management Science, 35: 1504-1511.

Doney, P., Cannon, J., \& Mullen, R. (1998). Understanding the influence of national culture on the development of trust. Academy of Management Review, 23(3): 601620.

Dwyer, F. R., Schurr, P. H., \& Oh, S. (1987). Developing buyer-seller relationship. Journal of Marketing, 511: 11-27.

Edelman, L. F., Brush, C. G., \& Manolova, T. (2005). Co-alignment in the resource Performance relationship: Strategy as mediator. Journal of Business Venturing, 20(3): 359-383.

Eisenhardt, K. M. (1989). Agency theory: An assessment and review. Management Review, 14(1): 57-74.

Eisenhardt, K. M., \& Bourgeois, L. J. (1988). Politics of strategic decision making in highvelocity environments: Toward a midrange theory. Academy of Management Journal, 31: 737-770.

Eisenhardt, K. M., \& Martin, J. A. (2000). Dynamic capabilities: What are they? Strategic Management Journal, 21: 1105-1121.

Eisenhardt, K. M., \& Schoonhoven, C. B. (1990). Organizational growth: Linking founding team, strategy, environment, and growth among US semiconductor ventures, 1978-1988. Administrative Science Quarterly, 35: 504-529.

Ellram, L. M., \& Hendrick, T. E. (1995). Partnering characteristics: A dyadic perspective. Journal of Business Logistics, 16(1): 41-64. 
Ensley, M., Pearce, C. L., \& Hmieleski, K. M. (2006). The moderating effect of environmental dynamism on the relationship between entrepreneur leadership behavior and new venture performance. Journal of Business Venturing, 21: 243-263.

Flint, D. (2004). Strategic marketing in global supply chains: Four challenges. Industrial Marketing Management, 33: 45-50.

Frederickson, J. W. (1984). Strategic decision processes: Comprehensiveness and performance in an industry with an unstable environment. Academy of Management Journal, 27(2): 399-424.

Gabbay, S. M., \& Zuckerman, E. W. (1998). Social capital and opportunity in corporate R\&D: The contingent effect of contact density on mobility expectations. Social Science Research, 27: 189-217.

Ganesan, S. (1994). Determinants of long-term orientation in buyer-seller relationships. Journal of Marketing, 58(2): 1-19.

Ganesan, S. (1996). The Yaksha security system. Communications of the ACM, 39(3): $55-$ 60.

Godfrey, P. C., \& Hill, C. W. L. (1995). The problem of unobsversables in strategic management research. Strategic Management Journal, 16: 519-533.

Goetz, C. J., \& Scott, R. E. (1981). Acquiring firms of relational contracts. Virginia Law Review, 676: 1089-1150.

Golden, B. R. (1992). The past is the past: Or is it? The use of retrospective accounts. Academy of Management Journal, 35(4): 848-861.

Grant, R. M. (1996). Toward a knowledge-based theory of the firm. Strategic Management Journal, 19(Special Issue): 109-122.

Greene, C., \& Organ, D. W. (1973). An evaluation of US models linking the received role with job-satisfaction. Administrative Science Quarterly, 18(1): 95-108.

Griffin, A., \& Hauser, J. R. (1996). Integrating R\&D and marketing: A review and analysis of the literature. Journal of Product Innovation Management, 13(3): 191215.

Gruen, T., Summers, J., \& Acito, F. (2000). Relationship marketing activities, commitment and membership behaviors in professional associations. Journal of Marketing, 64(3): 34-49.

Gummesson, E. (1996). Relationship marketing and imaginary organizations: A synthesis. European Journal of Marketing, 30(2): 31-44.

Hair, J., Anderson, R., Tatham, R., \& Black, W. (1998). Multivariate data analysis. Upper Saddle, New Jersey: Prentice Hall.

Hambrick, D. C., \& Cannella, A. (1993). Relative standing: A framework of understanding departure of acquired executives. Academy of Management Journal, 36: 733762

Hambrick, D. C., Geletkanycz, M. A., \& Fredrickson, J. W. (1993). Top executive commitment to the status quo: Some tests of its determinants. Strategic Management Journal, 14(6): 401-419.

Handfield, R. B., \& Nichols, E. L., Jr. (2004). Key issues in global supply base management. Industrial Marketing Management, 33(1): 29-36.

Harland, C., Caldwell, N., Power, P., \& Zheng, J. (2007). Barriers to supply chain information integration: SMEs adrift of eLands. Journal of Operations Management, 25: $1234-1254$

Harvey, M., \& Richey, F. (2001). Global supply chain management: The selection of globally competent managers. Journal of International Management, 7: 105-118.

Hennig-Thurau, T., Gwinner, K., \& Gremler, D. (2002). Understanding relationship marketing outcomes: An integration of relational benefits and relationship quality. Journal of Service Research, 4(February): 230-247.

Hibbard, J., Brunel, F., Dant, R., \& lacobucci, D. (2001). Does relationship marketing age well? Business Strategy Review, 12(4): 29-35.

Hodges, J. (2009, January 8). Links takes top spot in 2008 global M\&A rankings. Legalweek.

Huber, G. P., \& Power, D. J. (1985). Retrospective reports of strategic level managers: Guidelines for increasing their accuracy. Strategic Management Journal, 6: 171-180.

Hult, G., Tomas, M., Hurley, R. F., \& Knight, G. A. (2004). Innovativeness: Its antecedents and impact on business performance. Industrial Marketing Management, 33(5): 429-438.

Hunt, S., \& Morgan, R. (1994). Relationship marketing in the era of network competition. Marketing Management, 3(1): 19-28.

Iacobucci, D., \& Ostrom, A. (1996). Commercial and interpersonal relationships: Using the structure of interpersonal relationships to understand individual-to-individual, individual-to-firm, and firm-to-firm relationships in commerce. International Journal of Research in Marketing, 13(1): 53-72.

Ireland, R. D., \& Hitt, M. A. (1999). Achieving and maintaining strategic competitiveness in the 21st century: The role of strategic leadership. Academy of Management Executive, 13(1): 43-57.

James, D. R., \& Soref, M. (1981). Profit constraints on managerial autonomy: Managerial theory and the unmaking of the corporation president. American Sociological Review, 46(1): 1-18.

Jemison, D. B., \& Sitkin, S. B. (1986). Corporate acquisitions: A process perspective. Academy of Management Review, 11: 145-163.

Jensen, M. C. (1986). Agency costs of free cash flows, corporate finance, and takeovers. American Economic Review, 76: 323-329.

Johnson, J. (1999). Strategic integration in industrial distribution channels: Managing the interfirm relationship as a strategic asset. Journal of the Academy of Marketing Science, 27(1): 4-18.

Joshi, A. (1993). Long-term relationships, strategic partners and networks: A contingency theory of relational marketing. AMA Educators Conference, Proceedings ( $\mathrm{pp}$. 159-166).

Kalwarski, T. (2010, February 1). Getting in on the M\&A Action. BusinessWeek

Keats, B., \& Hitt, M. (1988). A US model of linkages among environmental dimensions, macro organizational characteristics, and performance. Academy of Management Journal, 31(3): 570-598.
Kusewitt, J. B. (1995). An exploratory study of strategic acquisition factors relating to performance. Strategic Management Journal, 6(2): 151-170.

Landeros, R., Reck, R., \& Plank, R. E. (1995). Maintaining buyer-supplier relationships. International Journal of Purchasing and Materials Management, 31(3): 3-11.

Lanier, D., Wempe, W., \& Zacahria, Z. (2010). Concentrated supply chain membership and financial performance: Chain- and firm-level perspectives. Journal of Operations Management, 28: 1-16.

Lau, C., \& Ngo, H. (2001). Organization development and organization performance. Journal of International Business Studies, 32(1): 95-114.

Lee, Y., \& Cavusgil, S. T. (2006). Enhancing alliance performance: The effects of contractual-based versus relationship-based governance. Journal of Business Research, 59(8): 896-905.

Lepak, D. P., \& Snell, S. A. (1998). Virtual HR: Strategic human resource management in the 21st century. Human Resource Management Review, 8(3): 215-235.

Lepak, D. P., \& Snell, S. A. (1999). The human architecture: Toward a theory of human capital allocation and development. Academy of Management Review, 24: 31-48.

Lippman, S. A., \& Rumelt, R. P. (1982). Uncertain imitability: An analysis of interfirm differences in efficiency under competition. Bell Journal of Economics, 13(2): 418438

Lu, L. Y. Y., \& Yang, C. (2004). The R\&D and marketing cooperation across new product development stages: An empirical study of Taiwan's IT industry. Industrial Marketing Management, 33(7): 593-605.

Lumpkin, G. T., \& Dess, G. G. (2001). Linking two dimensions of entrepreneurial orientation to firm performance: The moderating role of environment and industry life cycle. Journal of Business Venturing, 16(5): 429-452.

Lusch, R. F., \& Brown, J. R. (1996). Interdependency, contracting, and relationship behavior in marketing channels. Journal of Marketing, 60(4): 19-38.

Markides, C.C. (1992). Consequences of corporate refocusing: Ex ante evidence. Academy of Management Journal, 35: 398-412.

Markides, C. C., \& Williamson, P. J. (1994). Related diversification, core competences, and corporate performance. Strategic Management Journal, 15(Special Issue): 149165.

McGrath, R. G. (2001). Exploratory learning, innovative capacity, and managerial oversight. Academy of Management Journal, 24: 118-131.

Miles, M. P., \& Covin, J. G. (2002). Exploring the practice of corporate venturing: Some common forms and their organizational implications. Entrepreneurship Theory and Practice, 26: 21-40.

Miller, D., \& Shamsie, J. (1996). The resource based view of the organization in two environments: The Hollywood film studios from 1936 to 1965. Academy of Management Journal, 39(3): 519-543.

Montgomery, C. A. (1994). Corporate diversification. Journal of Economic Perspectives, 8 : $163-178$.

Morrison, E. W., \& Robinson, S. L. (1997). When employees feel betrayed: A model of how psychological contract violation develops. Academy of Management Review, 22: 226-256.

Moshieri, C., \& Campa, J. (2009, November). The European M\&A industry: A market in the process of construction. Academy of Management Perspectives, 71-86.

Pablo, A. L. (1994). Determinants of acquisition integration level: A decision-making perspective. Academy of Management Journal, 37(4): 803-836.

Palmatier, R., Dant, R., Grewal, D., \& Evans, K. (2006). Leveraging relationship marketing strategies for better performance: A meta-analysis. Journal of Marketing, 70: 136153.

Penrose, E. (1959). The theory of the growth of the firm. Oxford: Basil Blanchard.

Peteraf, M. A. (1993). The cornerstones of competitive advantage: A resource based view. Strategic Management Journal, 14: 179-191.

Pisano, G. P. (1990). The R\&D boundaries of the firm: An empirical analysis. Administrative Science Quarterly, 35: 153-176.

Quinn, J. B. (1992). The intelligent enterprise a new paradigm. The Executive, 6(4): 4864.

Quinn, R. E., \& Cameron, K. (1983). Organizational life-cycles and shifting criteria of effectiveness: Some preliminary evidence. Management Science, 29(1): 33-52.

Raja, U., Johns, G., \& Ntalianis, F. (2004). The impact of personality on psychological contracts. Academy of Management Journal, 47: 350-367.

Rousseau, C. (1989). Psychological and implied contracts in organizations. Employee Responsibilities and Rights Journal, 2: 121-139.

Sharfman, M. P. (1998). On the advisability of using CEOs as the sole informant in strategy research. Journal of Managerial Issues, 10(3): 373-392.

Srinivasan, R., \& Moorman, C. (2005). Strategic firm commitments and rewards for customer relationship management in online retailing. Journal of Marketing, 69(October): 193-200

Srivastava, R. K., Shervani, T. A., \& Fahey, L. (1998). Market-based assets and shareholder value: A framework for analysis. Journal of Marketing, 62(1): 2-18.

Stank, T., Keller, S., \& Closs, R. (2001a). Performance benefits of supply chain integration. Transportation Journal, 41(2/3): 32-46.

Stank, T. P., Keller, S. B., \& Daugherty, P. J. (2001b). Supply chain collaboration and logistical service performance. Journal of Business Logistics, 22(1): 29-48.

Thomson, N., \& McNamara, P. (2001). Achieving post-acquisition success: The role of corporate entrepreneurship. Long Range Planning, 34: 669-697.

Tomaskovic-Devey, D., Leiter, J., \& Thompson, S. (1994). Organizational survey nonresponses. Administrative Science Quarterly, 39: 439-457.

Tosi, H., Aldag, R., \& Storey, R. (1973). On the measurement of environment: An assessment of the Lawrence and Lorsch environmental uncertainty questionnaire. Administrative Science Quarterly, 18: 27-36.

Turnley, W. H., Bolino, M. C., Lester, S. W., \& Bloodgood, J. M. (2004). The effects of psychological contract breach on union commitment. Journal of Occupational and Organizational Psychology, 77(3): 421-428. 
Tushman, M., \& Romanelli, E. (1985). Organizational evolution. A metamorphosis model of convergence and reorientation. In Cummings, L. L., \& Staw, B. M. (Eds.), Research in organizational behavior (Vol. 7, pp. 171-222). Greenwich, CT: JAI Press.

Vainio, A. M. (2005). Exchange and combination of knowledge-based resources in network relationships: A study of software firms in Finland. European Journal of Marketing, 39(9/10): 1078-1095.

Vickery, S., Calantone, R., \& Droge, C. (2006). Supply chain flexibility: An empirical study. Journal of Supply Chain Management, 35(3): 16-24.

Wall Street Journal (2006, February 3). How to cash in on the M\&A boom.

Weaver, G. R., Trevino, L. K., \& Cochran, P. L. (1999). Integrated and decoupled corporate social performance: Management commitments, external pressures, and corporate ethics practices. Academy of Management Journal, 42(5): 539553.

Wernerfelt, B. (1984). A resource based view of the organization. Strategic Management Journal, 5: 171-180.
Whipple, J. M., Frankel, R., \& Daugherty, P. J. (2001). Information support for supply chain value networks: Performance implications. Journal of Business Logistics, 23(2): 67-81.

Wiersema, M. F., \& Bantel, K. A. (1993). Top management team turnover as an adaptation mechanism: The role of the environment. Strategic Management Journal, 14(7): 485-504.

Wiklund, J., \& Shepherd, D. (2005). Entrepreneurial orientation and small business performance: A configurational approach. Journal of Business Venturing, 20: 7191.

Woo, C. Y., Willard, G. E., \& Daellenbach, U. S. (1992). Spin-off performance: A case of overstated expectations? Strategic Management Journal, 13: 433-477.

Wright, P., Dunford, B., \& Snell, S. (2001). Human resources and the resource based view of the firm. Journal of Management, 27: 701-721.

Zacharakis, A., \& Meyer, G. D. (2000). The potential of actuarial decision models: Can they improve the venture capital investment decision? Journal of Business Venturing, 15(4): 323-347. 